\title{
Mutation-Independent Activation of the Anaplastic Lymphoma Kinase in Neuroblastoma
}

Marie Regairaz, ${ }^{*}$ Fabienne Munier, ${ }^{*}$ Hervé Sartelet, ${ }^{* \dagger}$ Marine Castaing, ${ }^{\ddagger}$ Virginie Marty, ${ }^{\S}$ Céline Renauleaud, ${ }^{*}$ Camille Doux, ${ }^{*}$ Jean Delbé, ${ }^{\top}$ José Courty, ${ }^{\top}$ Monique Fabre, Shigeru Ohta, ** Philippe Viehl, ${ }^{\circledR \dagger \dagger}$ Stefan Michiels, ${ }^{\ddagger}$ Dominique Valteau-Couanet, and Gilles Vassal*

\begin{abstract}
From the Laboratory for Vectorology and Anticancer Therapeutics, ${ }^{*}$ Gustave Roussy, Paris-Sud University, Centre National de la Recherche Scientifique Unité Mixte de Recherche 8203, Villejuif, France; the Sainte Justine University Hospital Center, ${ }^{\dagger}$ University of Montréal, Montréal, Québec, Canada; the Departments of Biostatistics and Epidemiology, ${ }^{\ddagger}$ Pathology and Biobank, ${ }^{\dagger \dagger}$ and Pediatrics,${ }^{\ddagger \dagger}$ Gustave Roussy, Villejuif, France; the Histocytopathology Unit,${ }^{\S}$ Laboratory of Translational Research, Gustave Roussy, Villejuif, France; the Research on Cell Growth, ${ }^{\mathbb{\top}}$ Tissue Repair and Regeneration (CRRET), Centre National de la Recherche Scientifique, University Paris-Est Créteil, Créteil, France; the Department of Pathology," Bicêtre Hospital, Le Kremlin-Bicêtre, France; and the Department of Pediatrics, ** Shiga University of Medical Science, Otsu, Shiga, Japan
\end{abstract}

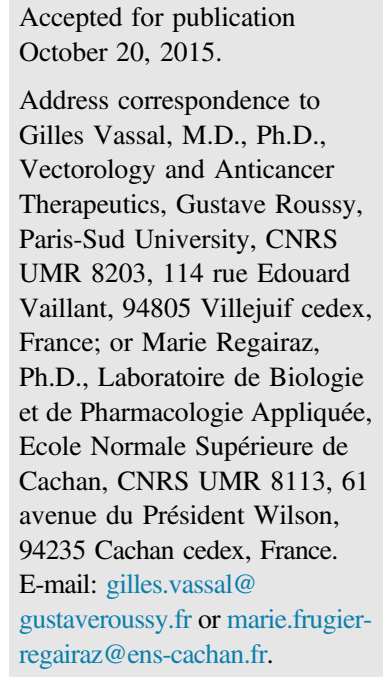

\begin{abstract}
Activating mutations of anaplastic lymphoma kinase $(A L K)$ have been identified as important players in neuroblastoma development. Our goal was to evaluate the significance of overall ALK activation in neuroblastoma. Expression of phosphorylated ALK, ALK, and its putative ligands, pleiotrophin and midkine, was screened in 289 neuroblastomas and 56 paired normal tissues. ALK was expressed in $99 \%$ of tumors and phosphorylated in $48 \%$ of cases. Pleiotrophin and midkine were expressed in $58 \%$ and $79 \%$ of tumors, respectively. ALK activation was significantly higher in tumors than in paired normal tissues, together with ALK and midkine expression. ALK activation was largely independent of mutations and correlated with midkine expression in tumors. ALK activation in tumors was associated with favorable features, including a younger age at diagnosis, hyperdiploidy, and detection by mass screening. Antitumor activity of the ALK inhibitor TAE684 was evaluated in wild-type or mutated ALK neuroblastoma cell lines and xenografts. TAE684 was cytotoxic in vitro in all cell lines, especially those harboring an ALK mutation. TAE684 efficiently inhibited ALK phosphorylation in vivo in both F1174I and R1275Q xenografts but demonstrated antitumor activity only against the R12750 xenograft. In conclusion, ALK activation occurs frequently during neuroblastoma oncogenesis, mainly through mutation-independent mechanisms. However, ALK activation is not associated with a poor outcome and is not always a driver of cell proliferation and/or survival in neuroblastoma. (Am J Pathol 2016, 186: 435-445; http://dx.doi.org/10.1016/j.ajpath.2015.10.016)
\end{abstract}

Neuroblastoma is a pediatric malignant tumor derived from primitive cells of the sympathetic nervous system and is one of the most common childhood tumors. Prognosis of neuroblastoma is remarkably variable, ranging from favorable neuroblastomas that can regress spontaneously to unfavorable neuroblastomas that are refractory to treatment, even intensive chemotherapy. 1,2 Biological events underlying neoplastic transformation of normal neuroblastic cells and their subsequent commitment into one of these two forms of the disease are still poorly understood. Anaplastic lymphoma kinase $(A L K)$ has been identified as the major neuroblastoma predisposition gene. ${ }^{3,4}$ Oncogenic mutations of $A L K$ (occurring mostly at positions F1174 and R1275) may be responsible for most familial neuroblastoma cases and account for $7 \%$ to $8 \%$ of somatic neuroblastoma cases. ${ }^{3-8}$ In addition, $A L K$ amplifications are detected in $2 \%$ of primary tumors. ${ }^{7,8}$

Supported by the Ministère de la Recherche et de l'Enseignement Supérieur (M.R.), the Association pour la Recherche contre le Cancer (M.R.), the Cancéropôle-Ile de France (F.M.), the Association Hubert Gouin (M.R., G.V.), the Fondation Charles Bruneau (H.S.), and the Institut National du Cancer (G.V.).

Disclosures: None declared.

Current address of M.R., Ecole Normale Supérieure de Cachan, Laboratoire de Biologie et de Pharmacologie Appliquée, Cachan, France. 
$A L K$ is also involved in chromosomal translocations, resulting in the formation of ALK fusion proteins. These translocations have been observed mostly in anaplastic large cell lymphomas, inflammatory myofibroblastic tumors, and non-small-cell lung cancers. ${ }^{9} A L K$ genomic alterations are associated with constitutive ALK activation, ${ }^{3-6,9,10}$ which confers sensitivity to ALK inhibitors. ${ }^{9,11}$ The dual c-Met/ ALK inhibitor crizotinib (Xalkori) and the second-generation inhibitor ceritinib (Zykadia) have received approval from the US Food and Drug Administration for the treatment of $A L K$ rearranged non-small-cell lung cancers. Treatment of neuroblastoma patients with crizotinib has produced variable responses in a recent phase 1 study, ${ }^{12}$ and ceritinib is currently being evaluated in an international pediatric clinical trial. $^{13}$

Full-length ALK is frequently expressed in neuroblastoma, ${ }^{14-16}$ and it has been suggested that wild-type ALK could also represent a therapeutic target in this disease. ${ }^{15-19}$ The heparin-binding growth factors pleiotrophin (PTN) and midkine (MDK) have been identified as potential ALK ligands $\mathrm{s}^{20,21}$ and are both expressed in neuroblastoma. 22,23 PTN expression is more frequent in favorable cases, whereas MDK is expressed in almost all primary tumors. ${ }^{22,23}$

We hypothesized that ALK activation could occur independently of mutations in neuroblastoma and participate in the development and/or the progression of the disease in many more sporadic cases than those presenting $A L K$ mutations. We thus analyzed ALK activation in primary neuroblastoma tumors using an antibody against phosphorylated ALK (P-ALK). We also evaluated the antitumor activity of the ALK inhibitor TAE684 in wild-type or mutated $A L K$ neuroblastoma cell lines and xenografts.

\section{Materials and Methods}

\section{Patients}

Paired normal tissue and neuroblastoma samples were obtained from 289 patients who were treated and followed up at Hôpital Bicêtre/Institut Gustave Roussy (Le Kremlin-Bicêtre/ Villejuif, France), American Hospital (Reims, France), CHU Sainte-Justine (Montréal, Canada), and Shiga University of Medical Science (Otsu, Japan). These patients' conditions were diagnosed between July 1988 and March 2008, of which 234 were standard neuroblastomas and 55 were detected by mass screening. This study was approved by the institutional review boards at each of the participating centers, and informed consent was obtained from the children's parents. Tumors were classified according to the International Neuroblastoma Staging System. ${ }^{24}$ Clinical characteristics of the patients are summarized in Table 1.

\section{Tissue Microarray Construction and IHC}

All specimens were embedded in paraffin and examined after hematoxylin and eosin staining. A viable and representative
Table 1 Clinical Characteristics of the Patients

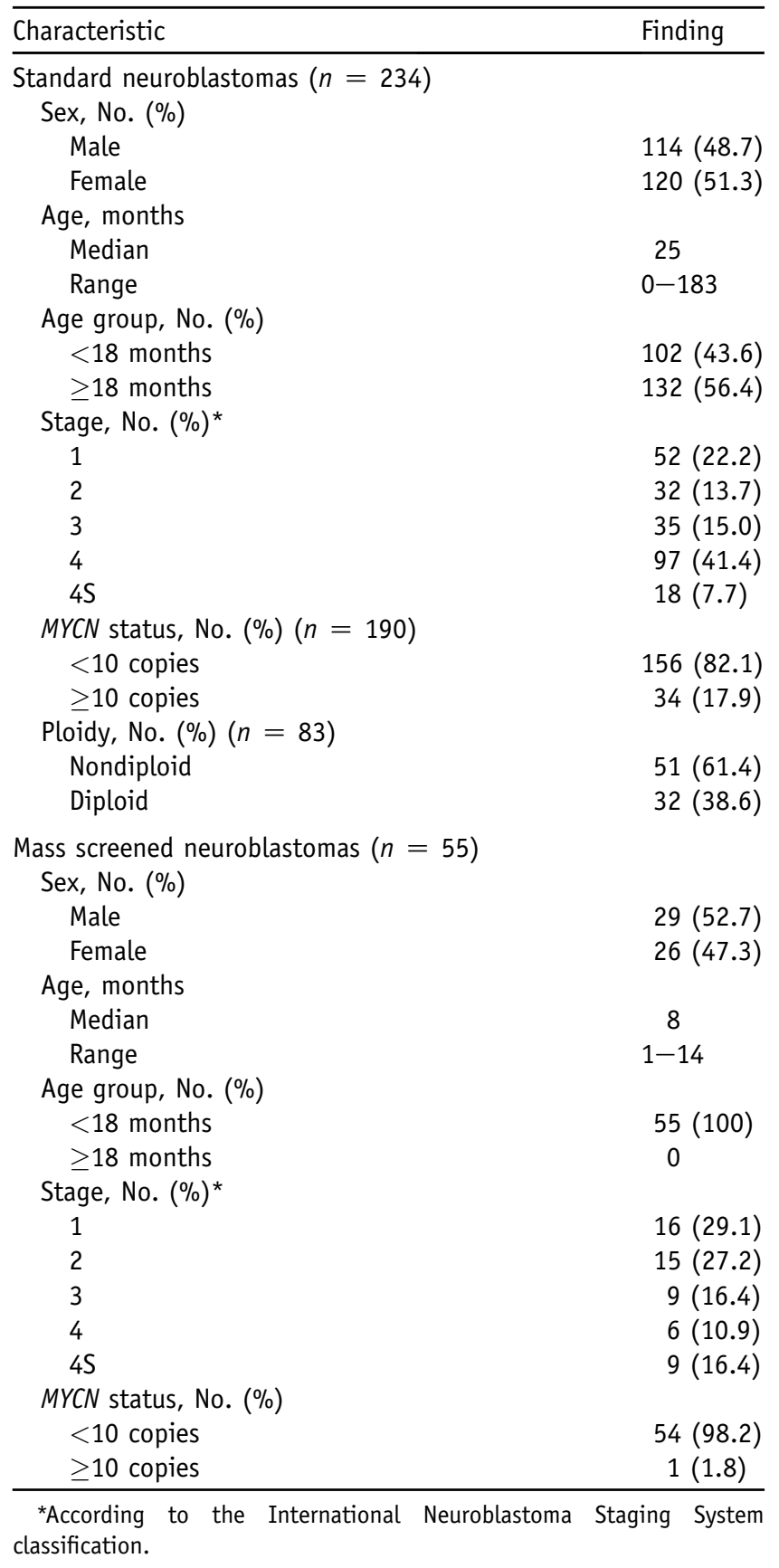

area of each specimen was sampled in quadruplicate into a recipient paraffin block using a tissue arrayer (Beecher Instruments, Sun Prairie, WI). Nine tissue microarray (TMA) blocks were constructed containing 289 primary neuroblastomas and 56 paired normal tissues (adrenal gland or sympathetic ganglia). TMA sections were antigen retrieved using water-bath heating in the following buffers: citrate buffer $\mathrm{pH}$ 7.3 (MM France, Francheville, France) for ALK, Target Retrieval Solution pH 9.9 (Dako, Glostrup, Denmark) for P-ALK, Target Retrieval Solution pH 9.0 (Dako) for PTN, and citrate buffer pH 6.0 (MM France) for MDK. Slides were subsequently incubated with anti-ALK (1/400 for 1 hour at 

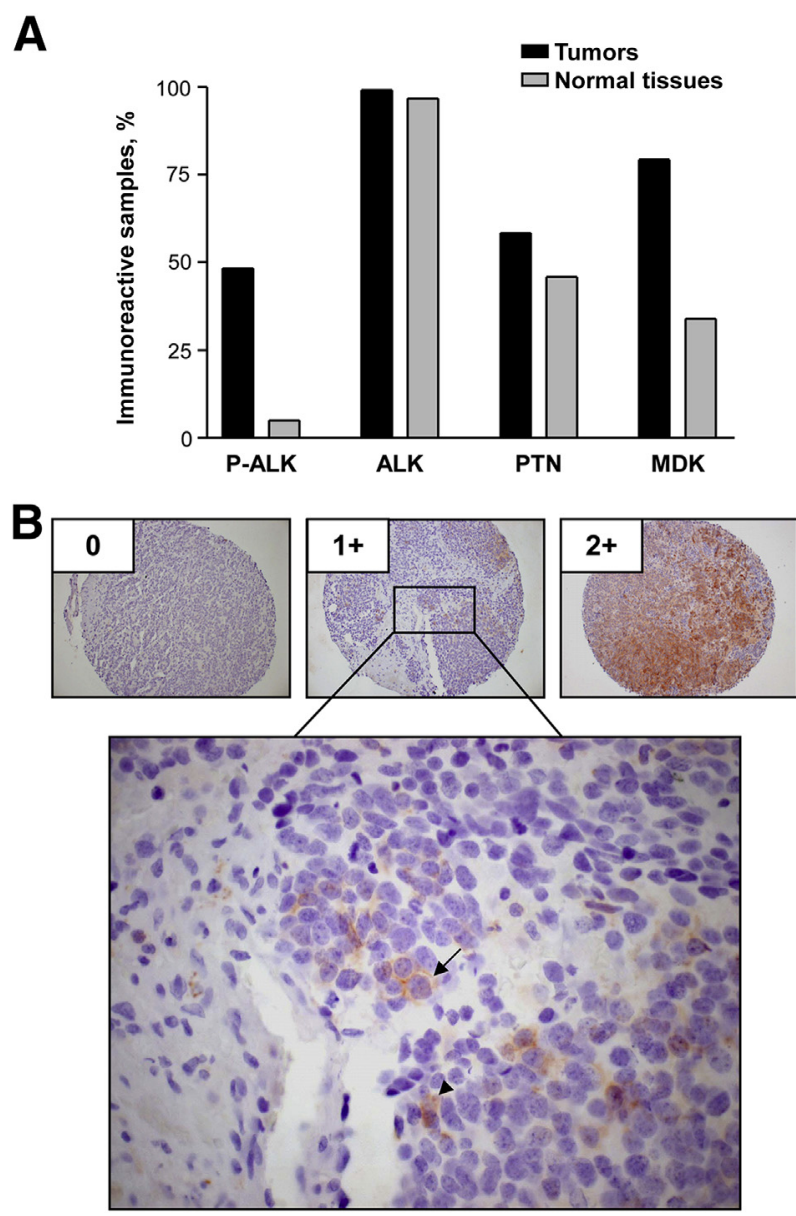

Figure 1 Characterization of anaplastic lymphoma kinase (ALK) activation in neuroblastoma. A: Detection of phosphorylated ALK (P-ALK), ALK, pleiotrophin (PTN), and midkine (MDK) in neuroblastic tumors and sympathetic normal tissues. Immunoreactive samples are those with an immunostaining score different from 0. B: Representative P-ALK staining patterns (immunostaining score $=0,1+$, or $2+$ ). Arrow and arrowhead indicate membrane and cytoplasmic P-ALK localization, respectively. Original magnification: $\times 250$ (top); $\times 630$ (bottom).

room temperature; Invitrogen, Carlsbad, CA), anti-P-ALK (Tyr1604) (1/50 overnight at $4^{\circ} \mathrm{C}$; Cell Signaling Technology, Danvers, MA), anti-PTN, or anti-MDK (1/400 and 1/100 for 1 hour at room temperature; R\&D Systems, Minneapolis, MN) antibodies. After incubation with peroxidase-conjugated secondary antibodies (EnVision+ for rabbit primary antibodies; Dako) or biotinylated secondary antibodies and peroxidasestreptavidin complexes (Vectastain Universal Quick kit; Vector Laboratories, Burlingame, CA), slides were covered with the chromogenic substrate diaminobenzidine (liquid DAB+; Dako) and counterstained with hematoxylin. Samples were scored semiquantitatively using the percentage of positive cells ( 0 , no labeling; $1+, 1 \%$ to $25 \%$ of positive cells; $2+, 26 \%$ to $50 \%$ of positive cells; $3+, 51 \%$ to $75 \%$ of positive cells; and $4+,>76 \%$ of positive cells). A median immunostaining score was calculated for each specimen and marker. To validate the specificity of the anti-P-ALK (Tyr1604) antibody in immunohistochemical (IHC) analyses, an $A L K$-rearranged anaplastic large cell lymphoma was used as a positive control and a large
B-cell lymphoma was used as a negative control. A control immunostaining was also performed with no primary antibody.

\section{Cell Lines and Transfections}

Nine human neuroblastoma cell lines derived from patients with advanced stages of disease were used as follows: IMR32, LAN-1, LAN-5, IGR-N91, IGR-NB8, NJB, SH-SY5Y, SK-N-AS, and SK-N-BE(2). ${ }^{25-27}$ All cells were grown in T25 flasks under standard cell-culturing conditions.

Cells seeded in 6-well plates were transfected with pcDNA3 or pcDNA3-ALK plasmids using Lipofectamine 2000 (Invitrogen). Transfectants were selected with G418 until colony formation, and G418-resistant clones were screened for ALK expression.

\section{ALK Sequencing}

Total RNA was extracted using the RNeasy kit (Qiagen, Hilden, Germany) and reverse transcribed using the Superscript III Reverse Transcriptase (Invitrogen). The resulting cDNA was used to amplify the tyrosine kinase domain of $A L K$ by PCR. PCR products were sequenced bidirectionally on an ABI 3730 automated sequencer (Applied Biosystems, Foster City, CA). The following primers were used: ALKTK1 forward $5^{\prime}$ CCGACTACAACCCCAACTACTGCT- $3^{\prime}$, ALKTK1 reverse 5'-CCCTTTCTATAGTAGCTCGCCCTGT-3', ALKTK2 forward 5'-CTTCATCCACCGAGACATTGCT-3', ALKTK2 reverse 5'-CTCAGGGTCCTTGGGCCT-3'.

\section{RPTP $\beta / \zeta$ Expression}

Total RNA was extracted and reverse transcribed as described above. A 240-bp coding region of PTPRZl (gene symbol for RPTP $\beta / \zeta$ ) was amplified by PCR using the following primers: $5^{\prime}$-GACCGTCTGGAAATGCGAAT- $3^{\prime}$ and $5^{\prime}$-TGAAACTCCTCCGCTGACA-3'. Total RNA from human U373 glioblastoma cells was used as a positive control. A $\beta$-actin PCR was performed to verify RNA/cDNA integrity (using primers $5^{\prime}$-TTCCTTCCTGGGCATGGAGT- $3^{\prime}$ and $5^{\prime}$-TCCTGCTTGCTGATCCACAT- $3^{\prime}$ ). PCR products were visualized after agarose gel electrophoresis.

Expression profiling analysis was performed using the publicly available Pediatric Xenograft \& Tumor Gene Expression Database ${ }^{28}$ which includes 163 samples (70 primary tumors, 75 xenografts, and 18 cell lines). The database was searched by querying PTPRZ1. Output median-centered $\log _{2}$ ratios were retrieved to build a bar chart.

\section{Cell Viability Assay}

TAE684 was kindly provided by Johannes Roesel (Novartis). Cells were seeded in 96-well plates to reach $30 \%$ of confluency at the time of treatment. Cell viability was measured by MTT assay (Sigma-Aldrich, St Louis, MO) after 72 hours of continuous exposure to TAE684. 
Table 2 ALK Mutation Analysis in P-ALK-Positive or - Negative NB Specimens

\begin{tabular}{llllll}
\hline & ALK tyrosine kinase & \multicolumn{4}{l}{ Immunoreactivity } \\
\cline { 3 - 6 } Sample & domain & P-ALK & ALK & PTN & MDK \\
\hline P-ALK-positive tumors & & & & \\
NB1 & Wild type & 3 & 4 & 0 & 3 \\
NB2 & Wild type & 2 & 4 & 2 & 3 \\
NB3 & Wild type & 1 & 2 & 1 & 1 \\
NB4 & Wild type & 1 & 2 & 1 & 2 \\
NB5 & Y1278S & 1 & 2 & 2 & 1 \\
NB6 & Wild type & 1 & 1 & 1 & 1 \\
NB7 & Wild type & 1 & 2 & 1 & 2 \\
NB8 & R12750 & 1 & 3 & 2 & 2 \\
NB9 & Wild type & 1 & 3 & 1 & 3 \\
NB10 & Wild type & 1 & 2 & 2 & 3 \\
NB11 & Wild type & 1 & 2 & 2 & 2 \\
NB12 & Wild type & 1 & ND & 0 & 1 \\
NB13 & R12750 & 1 & 2 & 1 & 1 \\
NB14 & F1174L & 1 & 3 & 2 & 4 \\
NB15 & Wild type & 1 & ND & 0 & 1 \\
P-ALK-negative tumors & & & & \\
NB16 & Wild type & 0 & 1 & 0 & 0 \\
NB17 & Wild type & 0 & 2 & 2 & 1 \\
NB18 & Wild type & 0 & 2 & 0 & 2 \\
NB19 & Wild type & 0 & 3 & 1 & 1 \\
NB20 & Wild type & 0 & 2 & 0 & 3 \\
NB21 & Wild type & 0 & 3 & 0 & 0 \\
NB22 & Wild type & 0 & 1 & 1 & 0 \\
NB23 & Wild type & 0 & 2 & 2 & 1 \\
\hline
\end{tabular}

ALK, anaplastic lymphoma kinase; MDK, midkine; NB, neuroblastoma; ND, not determined; P-ALK, phosphorylated ALK; PTN, pleiotrophin.

\section{In Vivo Experiments}

IGR-NB8R (wild-type $A L K$ ) and IGR-N835 (F1174I $A L K$ ) xenografts have been previously established at Gustave Roussy. ${ }^{27,29}$ IGR-NB8R is a CPT-11-resistant xenograft obtained after prolonged exposure of the patient-derived xenograft IGR-NB8 to CPT-1 $1^{27,29}$ and expressing high levels of ALK (unpublished results). The CLB-GA cell line $(\mathrm{R} 1275 \mathrm{Q} A L K)^{25}$ was kindly provided by Valérie Combaret (Centre Léon Bérard, Lyon, France). IGR-NB8R and IGRN835 xenografts (15- to $30-\mathrm{mm}^{3}$ fragments) or CLB-GA cells $\left(10^{7}\right)$ were implanted subcutaneously in 6- to 8 week-old female Swiss athymic mice. Animals bearing a 100 - to $300-\mathrm{mm}^{3}$ tumor were randomized into control or treatment groups $(n=5)$. The vehicle solution or TAE684 $(1,3$, or $10 \mathrm{mg} / \mathrm{kg})$ were administered p.o. once daily during 3 weeks. Tumor volumes were measured twice weekly. Experiments were performed under the conditions established by the European Union (directive 86/609/CEE).

\section{Western Blotting}

Cell pellets or frozen tumors were homogenized in lysis buffer $(50 \mathrm{mmol} / \mathrm{L}$ Tris- $\mathrm{HCl}[\mathrm{pH} 7.5], 250 \mathrm{mmol} / \mathrm{L} \mathrm{NaCl}, 5$ $\mathrm{mmol} / \mathrm{L}$ EDTA, $0.1 \% \mathrm{NP}-40$, supplemented with proteases and phosphatases inhibitors) before clearing by centrifugation. Secreted PTN and MDK proteins were recovered from conditioned media by heparin-sepharose purification. ${ }^{30}$ Proteins were separated by SDS-PAGE electrophoresis and immunoblotted with the following antibodies: antiPTN, anti-MDK (R\&D Systems), anti-ALK (Invitrogen), anti-P-ALK, anti-STAT3, anti- phosphorylated STAT3, anti-AKT, anti- phosphorylated AKT, anti-MAPK, antiphosphorylated MAPK (Cell Signaling Technology), and anti- $\beta$-actin (Sigma-Aldrich).

\section{Statistical Analysis}

Correlations between markers were evaluated with Spearman's correlation coefficient. The Wilcoxon signed-rank test was applied for the comparison of paired data. Association of markers with prognostic factors was assessed using the Mann-Whitney $U$-test, and their effect on overall survival was analyzed using the log-rank test. All analyses were conducted with SAS statistical software version 9.1 (SAS Institute Inc., Cary, NC). $P$ values were based on a two-sided hypothesis and were considered statistically significant when $<0.05$.

\section{Results}

ALK Activation Is Frequent and Mostly Independent of Mutations in Neuroblastoma

To determine the frequency of ALK activation in neuroblastoma, we analyzed the expression and activation of the receptor in 234 primary tumors using antibodies directed against total or P-ALK. The specificity of the anti-P-ALK antibody for IHC on formalin-fixed, paraffin-embedded tissues was first evaluated using relevant positive and negative controls. A specific nuclear and cytoplasmic staining was observed for both ALK and P-ALK in the positive control ( $A L K$-rearranged anaplastic large cell lymphoma), whereas no staining was detected in the negative control (large B-cell lymphoma) (Supplemental Figure S1).

In neuroblastomas, ALK was expressed in $99 \%$ of tumors and phosphorylated (ie, activated) in $48 \%$ of tumors (Figure 1A). Both ALK and P-ALK immunoreactivities were mostly cytoplasmic with occasional membrane staining (Figure 1B), consistent with the partial localization of ALK at the plasma membrane. ${ }^{31}$ ALK and P-ALK immunostaining scores positively correlated (Spearman correlation value $\rho=0.12, P=0.06$ ). Among P-ALK-positive tumors, $78 \%, 16 \%, 5 \%$, and $1 \%$ of cases had an immunostaining score of $1+, 2+, 3+$, and $4+$, respectively (Figure 1B).

Because the proportion of neuroblastic tumors with ALK activation was much higher than that described for the occurrence of $A L K$-activating mutations in neuroblastoma, ${ }^{7,8}$ we next sequenced the tyrosine kinase domain of $A L K$ in a subset of P-ALK-positive or -negative specimens. Four of 23 analyzed tumors had single-nucleotide substitutions 
A

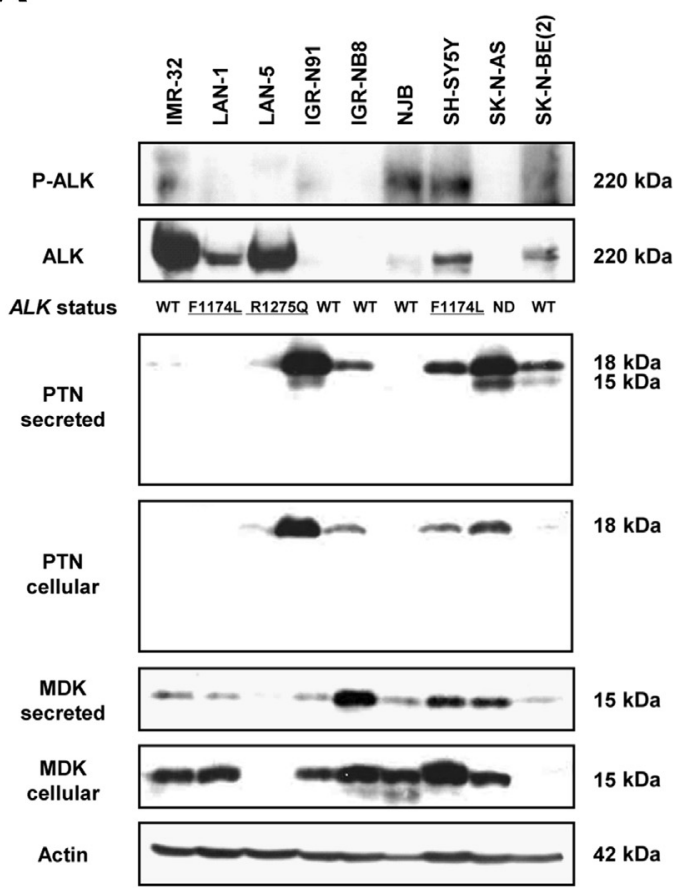

B

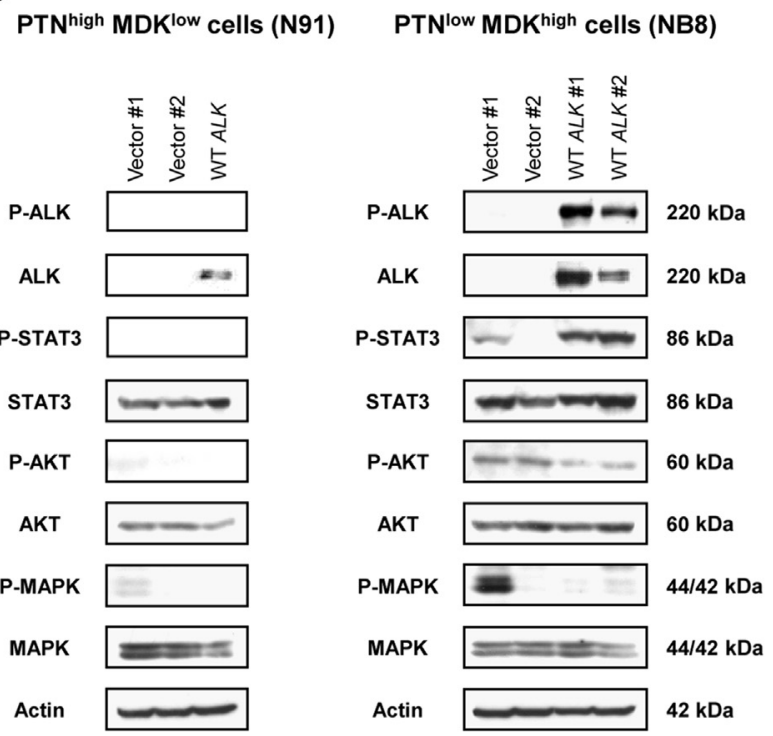

Figure 2 Effect of pleiotrophin (PTN) and midkine (MDK) ligands on anaplastic lymphoma kinase (ALK) activation in neuroblastoma cell lines. A: ALK mutation analysis and Western blot analysis of phosphorylated ALK (P-ALK), ALK, PTN, and MDK expression in a panel of nine human neuroblastoma cell lines. Actin was used as a loading control. B: Western blot analysis of ALK activation and downstream signaling in IGR-N91 (PTN ${ }^{\text {high }}$ ) or IGR-NB8 (MDK ${ }^{\text {high }}$ ) cells, stably transfected with a WT ALK expression vector (WT ALK) or with the corresponding empty vector (vector). Nos. 1 and 2 indicate different clones. Actin was used as a loading control. ND, not determined; WT, wild-type.

leading to previously reported mutations ${ }^{8}$ (Table 2). Remarkably, all $A L K$ mutated tumors were P-ALK positive (Table 2), suggesting that kinase domain mutations systematically lead to ALK activation in tumors. However, most P-ALK-positive tumors (11 of 15 ) were expressing a wildtype ALK receptor, revealing that ALK activation is mostly independent of mutations in neuroblastoma (Table 2).

\section{ALK Activation Correlates with MDK Expression in Neuroblastoma}

To gain further insights into the mechanisms underlying mutation-independent activation of ALK in neuroblastoma, we examined the potential involvement of the two reported ALK ligands, PTN and MDK, in this process. We first analyzed PTN and MDK expression in tumors and found that both proteins were largely expressed in neuroblastoma, with $58 \%$ of PTNpositive and 79\% of MDK-positive samples (Figure 1A).

Strikingly, ALK phosphorylation positively correlated with MDK expression (Spearman $\rho=0.17, P=0.006$ ) but not with PTN expression $(\rho=0.07, P=0.30)$, suggesting that MDK only is able to drive ALK activation in neuroblastoma. Most interestingly, MDK was expressed in all wild-type $A L K / \mathrm{P}-\mathrm{ALK}+$ tumors (Table 2).

In neuroblastoma cell lines, the expression and/or the secretion of PTN and MDK was detected in $60 \%$ and $90 \%$ of cell lines, respectively (Figure 2A). Among the different forms of PTN reported in the literature (showing different signaling properties and/or functions), ${ }^{32,33}$ we mostly detected the full-length protein $(18 \mathrm{kDa})$ in both cell extracts and conditioned media. PTN15 $(15 \mathrm{kDa})^{32}$ was observed as a minor form in the conditioned media of three cell lines (IGR-N91, SK-N-AS, and SK-N-BE(2)) (Figure 2A). No $A L K$ mutations were found in three of four $\mathrm{P}-\mathrm{ALK}-$ positive cell lines (IMR-32, NJB, and SK-N-BE(2)) (Figure 2A). To further confirm that a wild-type ALK receptor could be activated in neuroblastoma cells, ALK-negative neuroblastoma cell lines expressing high levels of PTN (IGR-N91) or MDK (IGRNB8) (Figure 2A) were stably transfected with a wild-type $A L K$ encoding vector. After selection of G418-resistant clones, ALK expression and activation were analyzed by Western blot. When expressed in IGR-N91 (PTN ${ }^{\text {high }}$ ) cells, ALK remained under its unphosphorylated form, and no change in downstream signaling was observed (Figure 2B). Conversely, ALK expression in IGR-NB8 (MDK ${ }^{\text {high }}$ ) cells was associated with ALK phosphorylation and downstream activation of STAT3 (Figure 2B). Altogether, these data suggest that at least MDK can activate ALK in neuroblastoma cells.

ALK Activation Correlates with a Neoplastic but not with an Aggressive Phenotype in Neuroblastoma

To determine whether ALK activation could participate in neuroblastoma initiation, we next compared ALK 


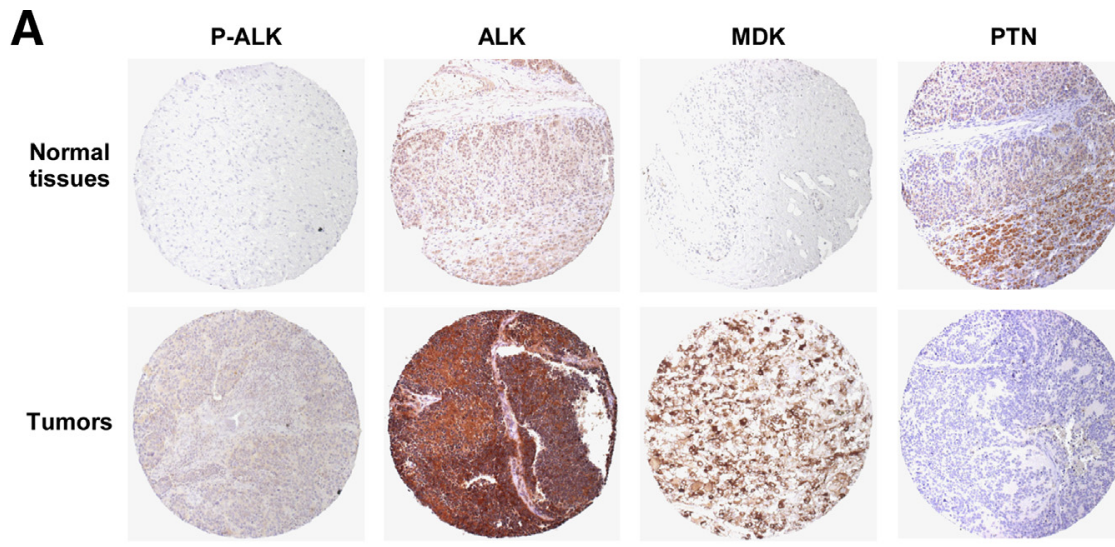

B

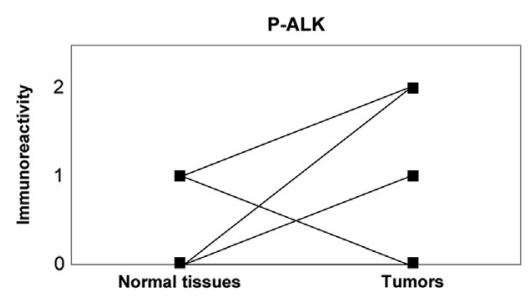

MDK

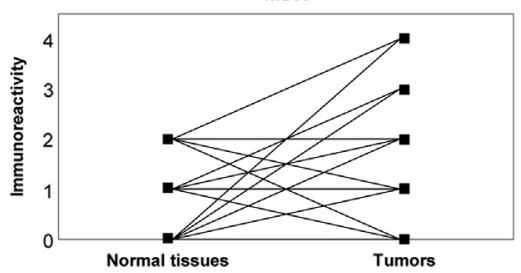

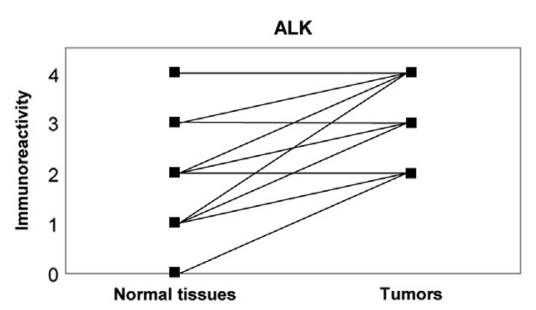

PTN

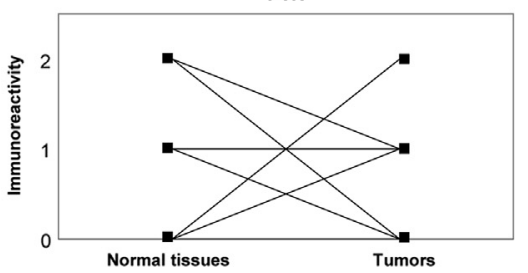

Figure 3 Phosphorylated anaplastic lymphoma kinase (P-ALK), anaplastic lymphoma kinase (ALK), midkine (MDK), and pleiotrophin (PTN) levels in paired sympathetic normal tissues and neuroblastic tumors. A: Representative photomicrographs of paired tissues. B: Comparison of immunostaining scores between paired normal tissues and tumors. Each line represents one (or more) patient(s). The total number of patients with paired normal and tumor tissues was 43 for $P$ ALK, 47 for ALK and MDK, and 45 for PTN. Original magnification: $\times 200($ A). phosphorylation between normal tissues and tumors. ALK was expressed in $97 \%$ of normal tissues (compared with $99 \%$ of tumors), whereas a P-ALK staining was observed in only $5 \%$ of normal tissues (versus $48 \%$ of tumors) (Figure 1A). Furthermore, comparison of immunostaining scores between paired tumors and normal tissues revealed that ALK was both activated $(P=0.0007)$ and overexpressed $(P<0.0001)$ in tumors compared with normal tissues (Figure 3).

To better understand the appearance of ALK activation in tumors, the expression of ALK ligands was examined in normal tissue and neuroblastoma samples. MDK was expressed in $34 \%$ of normal tissues (versus $79 \%$ of tumors), whereas PTN was detected in $46 \%$ of normal tissues (versus 58\% of tumors) (Figure 1A). Comparison of paired data revealed that MDK was expressed at higher levels in tumors compared with normal tissues $(P<0.0001)$, whereas PTN had an inverse tendency, being more expressed in normal tissues $(P=0.07)$ (Figure 3 ).

To determine whether ALK activation was related to prognosis in neuroblastoma, we next analyzed the association of the P-ALK marker with clinical and biological variables. We found that ALK activation was significantly associated with favorable prognosis factors, including a younger age at diagnosis $(P=0.0006)$ and absence of cell diploidy $(P=0.006)$ (Supplemental Figure S2A). However, overall survival was not significantly different between patients with P-ALK-negative and P-ALK-positive tumors (log-rank $P=0.46$ ). To further verify that ALK activation was associated with favorable prognosis in neuroblastoma, we examined P-ALK staining in a series of 55 neuroblastomas detected by mass screening. Mass screening programs have been initiated in several countries to detect neuroblastoma in infants and improve the outcome of the disease. However, these programs have found that tumors detected by mass screening almost invariably exhibit favorable features. ${ }^{34,35}$ As expected, ALK was activated more frequently in mass screened neuroblastomas than in standard tumors ( $84 \%$ versus $48 \%$ of P-ALK-positive samples). P-ALK levels were also higher in mass screened tumors $(P<0.0001)$ (Supplemental Figure S2B). Overall, ALK is thus more activated in favorable than in unfavorable neuroblastoma cases.

MDK expression did not correlate with any prognosis factor or with overall survival. However, PTN expression was significantly higher in favorable neuroblastomas, including those lacking $M Y C N$ amplification $(P=0.002)$ and those detected by mass screening $(P=0.03)$. These findings are consistent with previous reports. ${ }^{22,23}$ 


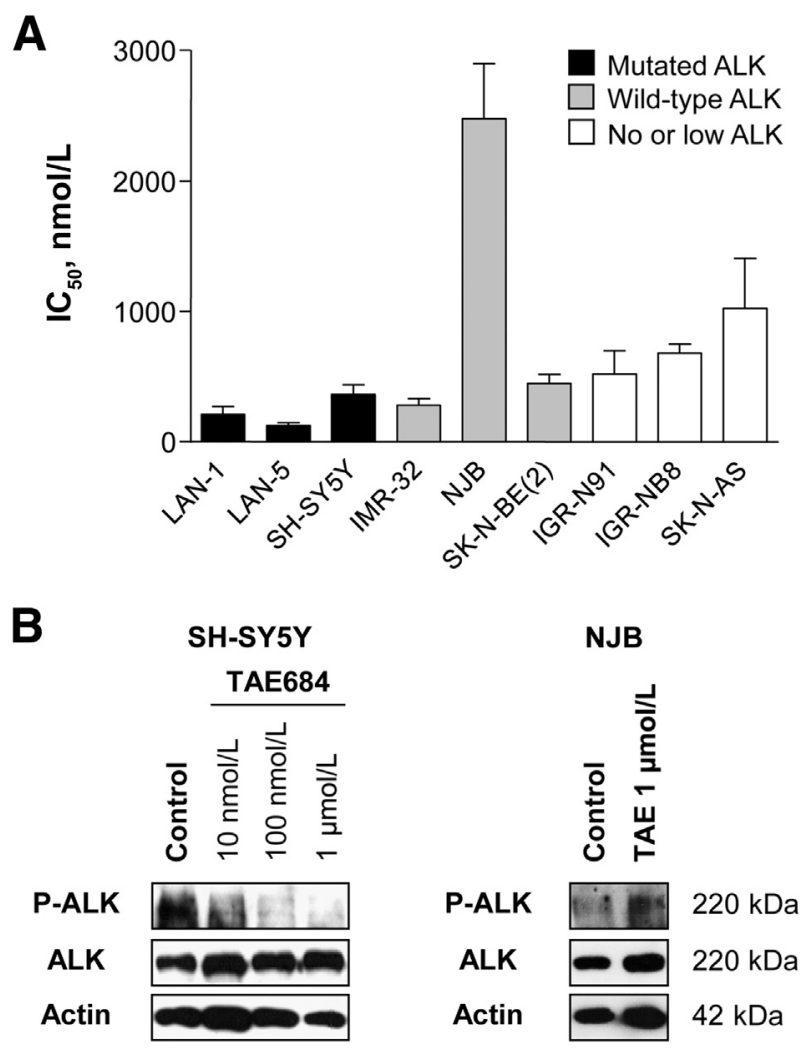

Figure 4 Pharmacologic inhibition of anaplastic lymphoma kinase (ALK) in neuroblastoma cell lines. A: Sensitivity to TAE684 in neuroblastoma cell lines expressing a mutated ALK, a wild-type ALK, or no ALK. Mean half maximal inhibitory concentration $\left(\mathrm{IC}_{50}\right.$ ) values \pm SEM from duplicate experiments are shown. B: Western blot analysis of ALK activation in SH-SY5Y and NJB cells treated with TAE684 during 6 hours. Actin was used as a loading control. P-ALK, phosphorylated ALK.

\section{Pharmacologic Inhibition of ALK}

To assess the significance of ALK activation as a therapeutic target in neuroblastoma, we examined the consequences of ALK kinase inhibition in neuroblastoma cell lines and xenografts by the small ALK inhibitor TAE684. ${ }^{36}$ TAE684 activity was first evaluated in vitro in a panel of nine neuroblastoma cell lines expressing either a wild-type or a mutated ALK receptor and presenting various levels of the total and phosphorylated forms of the protein (Figure 2A). After 72 hours of drug exposure, inhibition of cell proliferation by TAE684 was observed in all neuroblastoma cell lines with a half maximal inhibitory concentration $\left(\mathrm{IC}_{50}\right)$ of $150 \mathrm{nmol} / \mathrm{L}$ to $2.5 \mu \mathrm{mol} / \mathrm{L}$ (Figure 4A). All three $A L K$-mutated cell lines, as well as two of the three wild-type ALK/P-ALK + cell lines (IMR-32 and SK$\mathrm{N}-\mathrm{BE}(2))$, were the most sensitive to TAE684 $\left(\mathrm{IC}_{50}<500\right.$ $\mathrm{nmol} / \mathrm{L}$ ). Only one cell line had an $\mathrm{IC}_{50}>1 \mu \mathrm{mol} / \mathrm{L}(\mathrm{NJB})$. Consistent with these results, TAE684 was able to efficiently inhibit ALK phosphorylation in SH-SY5Y cells (F1174L $A L K)$ but did not decrease P-ALK levels in NJB cells (Figure 4B).

TAE684 activity was next evaluated in vivo in three neuroblastoma xenografts. Athymic mice bearing either a wild-type (IGR-NB8R) or a mutated $A L K$ (IGR-N835 or CLB-GA) neuroblastoma tumor were administered vehicle solution or TAE684 at 1,3 , or $10 \mathrm{mg} / \mathrm{kg}$ daily during 21 consecutive days. The compound was well tolerated up to the maximal dose of $10 \mathrm{mg} / \mathrm{kg}$ daily because maximal weight loss did not exceed a mean of $10 \%$ and no toxic deaths were observed (Supplemental Table S1). A strong inhibition of ALK phosphorylation was observed in both IGR-N835 and CLB-GA after 3 days of TAE684 treatment at $10 \mathrm{mg} / \mathrm{kg}$ daily (Figure 5, B and C). TAE684-mediated P-ALK inhibition was not observed in IGR-NB8R because no P-ALK signal was detectible in these tumors at basal level (Figure 5, B and C). Despite being used at in vivo pharmacologically active doses, TAE684 failed to show antitumor activity against both IGR-NB8R (wild-type $A L K)$ and IGR-N835 (F1174I ALK) xenografts. However, TAE684 proved to be very potent against the CLB-GA $(R 1275 Q \quad A L K)$ xenograft (Figure 5A). Remarkably, TAE684 induced CLB-GA tumor growth delay in a dosedependent manner (Figure 5A). Moreover, two complete regressions and one tumor-free survivor were observed at the maximal dose of $10 \mathrm{mg} / \mathrm{kg}$ daily (Supplemental Table S1). The antitumor activity of TAE684 correlated with abrogation of ALK downstream signaling because P-STAT3 and P-AKT levels were greatly reduced in CLB-GA xenografts after 3 days of treatment (Figure 5B). Conversely, no inhibition of ALK downstream effectors was observed in the TAE684-resistant IGR-N835 xenograft (Figure 5B). Unexpectedly, TAE684 treatment resulted in an increase in STAT3 and AKT phosphorylation in IGR-NB8R xenografts (Figure 5B).

\section{Discussion}

Identification of $A L K$ as the major familial neuroblastoma predisposition gene ${ }^{3}$ revealed that activation of this kinase is probably a key event in neuroblastoma pathogenesis and also provided a molecular rationale for targeted therapy using ALK-specific inhibitors in this disease. The $A L K$ gene encodes a receptor tyrosine kinase expressed primarily in the developing nervous system. ${ }^{37,38}$ In tumors, ALK fusion proteins are found in a variety of cancers, ${ }^{9}$ whereas fulllength ALK is expressed almost exclusively in tumors of neuroectodermal origin, especially in neuroblastomas. ${ }^{14-16}$ In the present study, we used an anti-P-ALK antibody to specifically detect the activated form of ALK in neuroblastoma samples. We demonstrated the specificity of the antibody in $\mathrm{ALK}^{+}$and $\mathrm{ALK}^{-}$lymphomas and in neuroblastoma xenografts treated with an ALK inhibitor. Recent studies reported that P-ALK could serve as a diagnostic and predictive biomarker in lung cancer using the same antibody. ${ }^{39,40} \mathrm{We}$ confirmed that ALK is ubiquitously expressed in neuroblastoma specimens and further demonstrated a high frequency of ALK activation in these tumors ( $48 \%$ of cases).

The molecular mechanisms underlying ALK activation in neuroblastoma are still largely unknown. Mutations in the 

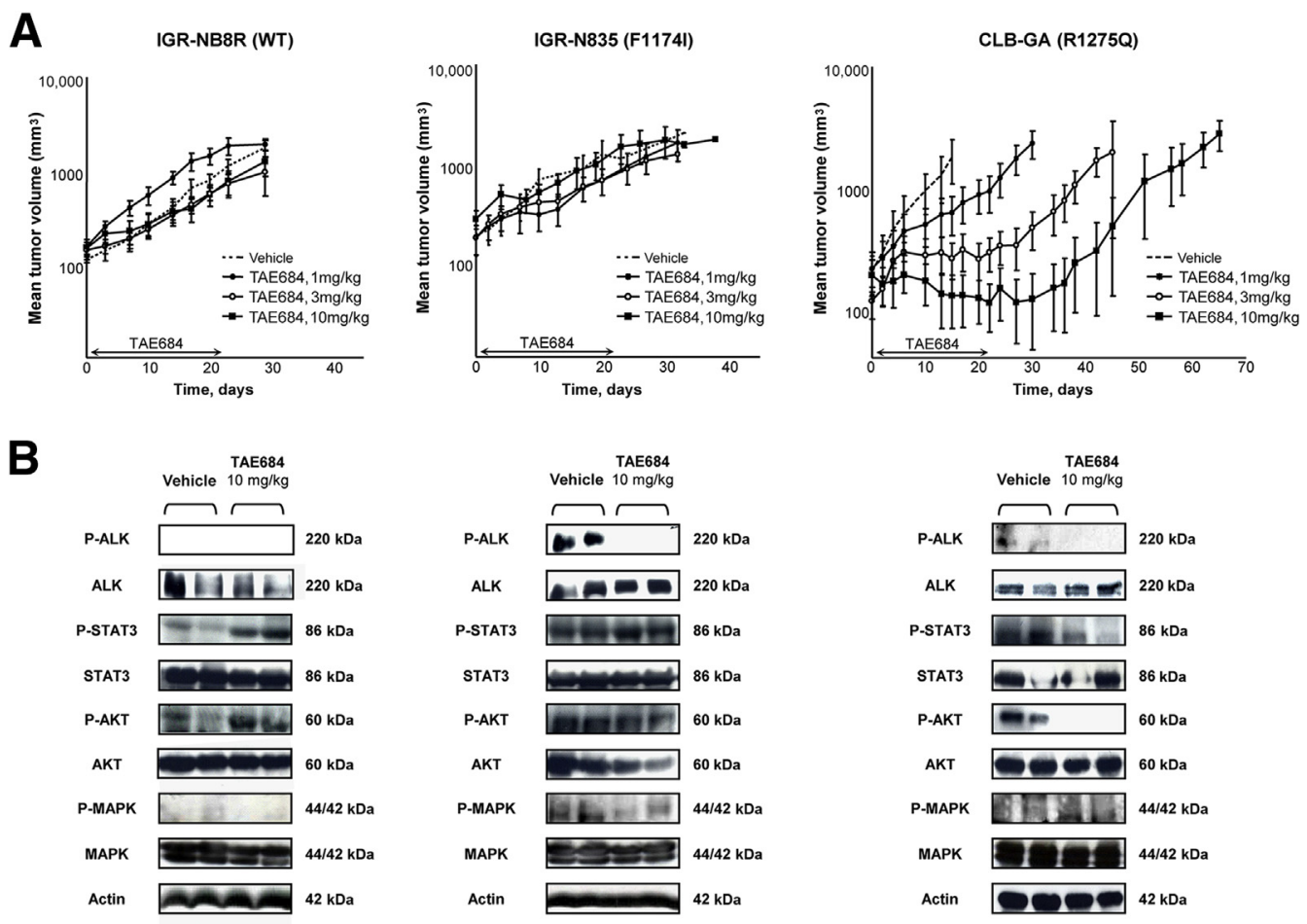

C
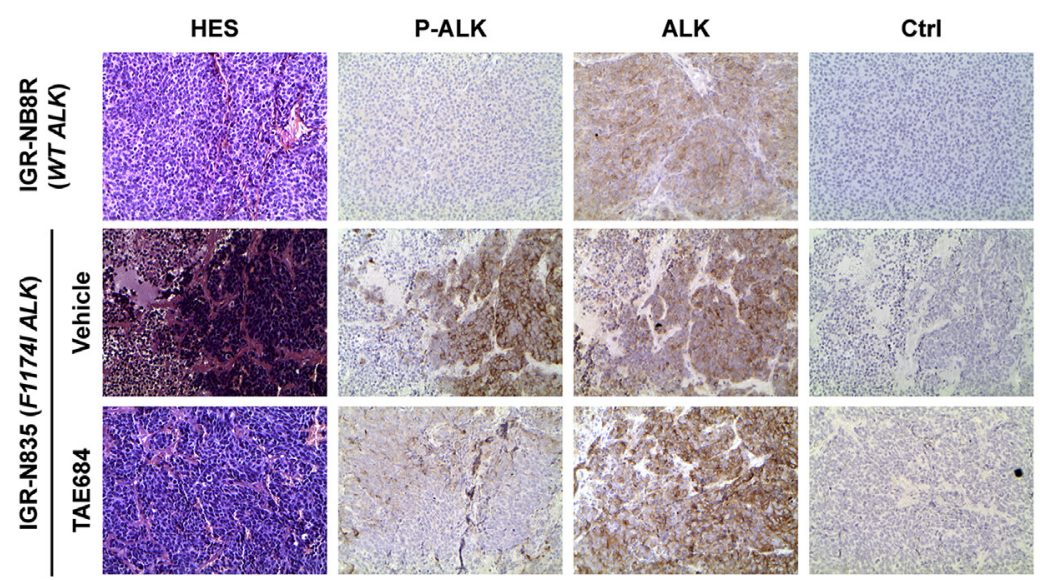

Figure 5 In vivo activity of the small-molecule anaplastic lymphoma kinase (ALK) inhibitor TAE684 against neuroblastoma xenografts with different $A L K$ mutation status. A: Evolution of tumor growth in IGR-NB8R [wild-type (WT) ALK], IGR-N835 (F1174I ALK), and CLB-GA (R1275Q ALK) neuroblastoma xenografts treated with vehicle solution or TAE684 at 1,3 , or $10 \mathrm{mg} / \mathrm{kg}$ daily during 21 consecutive days. Mean tumor volumes \pm SEM are shown. B: Western blot analysis of ALK activation and ALK downstream signaling in neuroblastoma xenografts treated with TAE684 at $10 \mathrm{mg} / \mathrm{kg}$ daily during 3 days. Two individual tumors implanted in mice were collected and analyzed. Actin was used as a loading control. C: Immunohistochemical staining of IGR-NB8R and IGR-N835 neuroblastoma xenografts using phosphorylated ALK (P-ALK) and ALK antibodies. A control immunostaining was performed with no primary antibody (ctrl). IGRN835 xenografts were treated with vehicle solution or TAE684 at $10 \mathrm{mg} / \mathrm{kg}$ daily during three days. Original magnification: $\times 200$ (C).

tyrosine kinase domain of ALK have been reported in $7 \%$ to $8 \%$ of sporadic neuroblastoma cases ${ }^{7,8}$ and have been found to constitutively activate the receptor in vitro. ${ }^{3-6,8,41,42} \mathrm{We}$ found that these mutations are indeed observed exclusively in P-ALK-positive specimens, but we also demonstrated that ALK activation is mainly independent of mutations in neuroblastoma.

In accordance with previous studies, ${ }^{22,23}$ we found that the two postulated ALK ligands, $\mathrm{PTN}^{20}$ and $\mathrm{MDK},{ }^{21}$ are frequently expressed in neuroblastoma (in 58\% and 79\% of tumors, respectively) and thus likely represent a major mechanism of ALK activation in neuroblastoma. Several observations indicated that MDK could trigger ALK activation in neuroblastoma. First, ALK phosphorylation is correlated with MDK expression in tumors. Second, ALK activation and overexpression in tumors (compared with normal tissues) are concomitant with MDK up-regulation. Finally, overexpression of a wild-type ALK receptor results in the induction of ALK signaling in a neuroblastoma cell line expressing high levels of MDK. These findings are consistent with independent studies reporting that MDK could serve as a physiologic ligand for ALK in different cell 
types, including sympathetic neurons. ${ }^{18,21,43}$ However, MDK expression does not systematically lead to ALK activation in neuroblastoma specimens (Table 2), suggesting that additional factors regulate P-ALK levels. The role of PTN in ALK activation has been controversial. ${ }^{20,32,44,45}$ Several forms of PTN have been described in the literature as having different signaling capabilities and/or functions. ${ }^{32,33}$ In glioblastoma cells, both PTN18 (18 kDa, full-length PTN) and PTN15 (15 kDa) have been observed, and only PTN15 was found to be able to trigger ALK activation and downstream signaling. ${ }^{32}$ Another study proposed that ALK activation by PTN occurs through an alternative mechanism of receptor tyrosine kinase activation via the RPTP $\beta / \zeta$. ${ }^{46}$ Interestingly, we mostly detected PTN18 in neuroblastoma cell lines (Figure 2A) and found that $\mathrm{RPTP} \beta / \zeta$ expression is low in neuroblastoma (Supplemental Figure S3). These findings could explain the apparent lack of ALK activation by PTN in neuroblastic cells.

The frequency of ALK activation in neuroblastoma raises the question of its biological role in this malignant tumor. Activating mutations of the ALK receptor occur in $80 \%$ of familial neuroblastoma cases $^{3,4}$ and confer a transforming potential to the ALK kinase, ${ }^{5-8,41}$ indicating that ALK activation might play a role in neuroblastoma oncogenesis. Recently, the F1174L $A L K$ mutation was found to collaborate with $M Y C N$ to induce neuroblastoma in zebrafish and mouse models. ${ }^{47-49}$ In the present study, we found that ALK is differentially phosphorylated between matched normal sympathetic tissues and primary tumors. ALK activation may therefore represent a major oncogenic event in neuroblastoma, occurring either by mutation (segregating in most neuroblastoma families or acquired de novo in $7 \%$ to $8 \%$ of sporadic cases) or through alternative mechanisms (such as MDK up-regulation).

The detection of P-ALK in both favorable and unfavorable neuroblastomas and the observation of higher P-ALK levels in favorable cases suggest that ALK activation is an early event initiating neuroblastoma, rather than a later event leading to progression of the disease. In a recent phase 1 evaluation of crizotinib in pediatric patients with refractory solid tumors or anaplastic large cell lymphomas, only one complete response was observed in $11 A L K$-mutated neuroblastoma cases. ${ }^{12}$ This low objective response rate could be explained in part by the fact that F1174 mutations induce resistance to crizotinib. ${ }^{8,42,50,51}$ In the present study, we used the TAE684 compound, which has demonstrated activity in models harboring the F1174L $A L K$ mutation. ${ }^{49-51}$ ALK targeting with TAE684 was cytotoxic in vitro against all neuroblastoma cell lines, especially those expressing a mutated or a wild-type phosphorylated ALK. TAE684 was able to efficiently inhibit ALK phosphorylation in vivo in both $A L K^{F 1174 I}$ and $A L K^{R 1275 Q}$ xenografts but demonstrated antitumor activity only against the $A L K^{R 1275 Q}$ xenograft. This observation indicates that ALK activation does not systematically drive cell proliferation and/or survival in neuroblastoma. Our results suggest that at least a subset of patients with a R1275Q mutated tumor could benefit from ALK targeting. Similar conclusions have been reached in neuroblastoma xenografts treated with crizotinib, ${ }^{42}$ and the only neuroblastoma patient responding to treatment in the phase 1 study had a R1275Q germline mutation. ${ }^{12}$ The ongoing clinical trial of the secondgeneration inhibitor ceritinib in pediatric malignant tumors with $A L K$ aberrations will determine whether ALK inhibition could be useful in the treatment of more neuroblastoma patients (in particular those presenting with a F1174 mutated tumor).

In conclusion, ALK activation is frequent and mainly independent of mutations in neuroblastoma. ALK is activated during neuroblastoma oncogenesis rather than during tumor progression, and the activated ALK receptor is not always an oncogenic driver in tumors. Innovative approaches and designs will be needed to identify ALKdriven tumors and develop ALK inhibitors in neuroblastoma.

\section{Acknowledgments}

We thank Drs. Estelle Dubus-Daudigeos, Sheena Aris, and François Dautry for technical assistance, editing, and helpful comments, respectively. TAE684 and the CLB-GA cell line were provided by Johannes Roesel (Novartis) and Valérie Combaret (Centre Léon Bérard, Lyon, France), respectively.

M.R., F.M., H.S., and G.V. designed research; M.R., F.M., V.M., C.R., C.D., J.D., and J.C. performed experiments; M.R., F.M., H.S., M.C., P.V., S.M., and G.V. analyzed data; H.S., M.F., S.O., and D.V.-C. collected clinical and pathological data; and M.R., H.S., and G.V. wrote the manuscript.

\section{Supplemental Data}

Supplemental material for this article can be found at http://dx.doi.org/10.1016/j.ajpath.2015.10.016.

\section{References}

1. Brodeur GM: Neuroblastoma: biological insights into a clinical enigma. Nat Rev Cancer 2003, 3:203-216

2. Maris JM: Recent advances in neuroblastoma. N Engl J Med 2010, 362:2202-2211

3. Mosse YP, Laudenslager M, Longo L, Cole KA, Wood A, Attiyeh EF, Laquaglia MJ, Sennett R, Lynch JE, Perri P, Laureys G, Speleman F, Kim C, Hou C, Hakonarson H, Torkamani A, Schork NJ, Brodeur GM, Tonini GP, Rappaport E, Devoto M, Maris JM: Identification of ALK as a major familial neuroblastoma predisposition gene. Nature 2008, 455:930-935

4. Janoueix-Lerosey I, Lequin D, Brugieres L, Ribeiro A, de Pontual L, Combaret V, Raynal V, Puisieux A, Schleiermacher G, Pierron G, Valteau-Couanet D, Frebourg T, Michon J, Lyonnet S, Amiel J, Delattre O: Somatic and germline activating mutations of the ALK kinase receptor in neuroblastoma. Nature 2008, 455:967-970

5. Chen Y, Takita J, Choi YL, Kato M, Ohira M, Sanada M, Wang L, Soda M, Kikuchi A, Igarashi T, Nakagawara A, Hayashi Y, Mano H, 
Ogawa S: Oncogenic mutations of ALK kinase in neuroblastoma. Nature 2008, 455:971-974

6. George RE, Sanda T, Hanna M, Frohling S, Luther W 2nd, Zhang J, Ahn Y, Zhou W, London WB, McGrady P, Xue L, Zozulya S, Gregor VE, Webb TR, Gray NS, Gilliland DG, Diller L, Greulich H, Morris SW, Meyerson M, Look AT: Activating mutations in ALK provide a therapeutic target in neuroblastoma. Nature 2008, 455:975-978

7. De Brouwer S, De Preter K, Kumps C, Zabrocki P, Porcu M, Westerhout EM, Lakeman A, Vandesompele J, Hoebeeck J, Van Maerken T, De Paepe A, Laureys G, Schulte JH, Schramm A, Van Den Broecke C, Vermeulen J, Van Roy N, Beiske K, Renard M, Noguera R, Delattre O, Janoueix-Lerosey I, Kogner P, Martinsson T, Nakagawara A, Ohira M, Caron H, Eggert A, Cools J, Versteeg R, Speleman F: Meta-analysis of neuroblastomas reveals a skewed ALK mutation spectrum in tumors with MYCN amplification. Clin Cancer Res 2010, 16:4353-4362

8. Bresler SC, Weiser DA, Huwe PJ, Park JH, Krytska K, Ryles H, Laudenslager M, Rappaport EF, Wood AC, McGrady PW, Hogarty MD, London WB, Radhakrishnan R, Lemmon MA, Mosse YP: ALK mutations confer differential oncogenic activation and sensitivity to ALK inhibition therapy in neuroblastoma. Cancer Cell 2014, 26:682-694

9. Hallberg B, Palmer RH: Mechanistic insight into ALK receptor tyrosine kinase in human cancer biology. Nat Rev Cancer 2013, 13: 685-700

10. Miyake I, Hakomori Y, Shinohara A, Gamou T, Saito M, Iwamatsu A, Sakai R: Activation of anaplastic lymphoma kinase is responsible for hyperphosphorylation of ShcC in neuroblastoma cell lines. Oncogene 2002, 21:5823-5834

11. McDermott U, Iafrate AJ, Gray NS, Shioda T, Classon M, Maheswaran S, Zhou W, Choi HG, Smith SL, Dowell L, Ulkus LE, Kuhlmann G, Greninger P, Christensen JG, Haber DA, Settleman J: Genomic alterations of anaplastic lymphoma kinase may sensitize tumors to anaplastic lymphoma kinase inhibitors. Cancer Res 2008, 68:3389-3395

12. Mosse YP, Lim MS, Voss SD, Wilner K, Ruffner K, Laliberte J, Rolland D, Balis FM, Maris JM, Weigel BJ, Ingle AM, Ahern C, Adamson PC, Blaney SM: Safety and activity of crizotinib for paediatric patients with refractory solid tumours or anaplastic large-cell lymphoma: a Children's Oncology Group phase 1 consortium study. Lancet 2013, 14:472-480

13. Barone G, Anderson J, Pearson AD, Petrie K, Chesler L: New strategies in neuroblastoma: therapeutic targeting of MYCN and ALK. Clin Cancer Res 2013, 19:5814-5821

14. Lamant L, Pulford K, Bischof D, Morris SW, Mason DY, Delsol G, Mariame B: Expression of the ALK tyrosine kinase gene in neuroblastoma. Am J Pathol 2000, 156:1711-1721

15. Passoni L, Longo L, Collini P, Coluccia AM, Bozzi F, Podda M, Gregorio A, Gambini C, Garaventa A, Pistoia V, Del Grosso F, Tonini GP, Cheng M, Gambacorti-Passerini C, Anichini A, FossatiBellani F, Di Nicola M, Luksch R: Mutation-independent anaplastic lymphoma kinase overexpression in poor prognosis neuroblastoma patients. Cancer Res 2009, 69:7338-7346

16. Duijkers FA, Gaal J, Meijerink JP, Admiraal P, Pieters R, de Krijger RR, van Noesel MM: High anaplastic lymphoma kinase immunohistochemical staining in neuroblastoma and ganglioneuroblastoma is an independent predictor of poor outcome. Am J Pathol 2012, 180:1223-1231

17. Schulte JH, Bachmann HS, Brockmeyer B, Depreter K, Oberthur A, Ackermann S, Kahlert Y, Pajtler K, Theissen J, Westermann F, Vandesompele J, Speleman F, Berthold F, Eggert A, Brors B, Hero B, Schramm A, Fischer M: High ALK receptor tyrosine kinase expression supersedes ALK mutation as a determining factor of an unfavorable phenotype in primary neuroblastoma. Clin Cancer Res 2011, 17:5082-5092

18. Reiff T, Huber L, Kramer M, Delattre O, Janoueix-Lerosey I, Rohrer H: Midkine and Alk signaling in sympathetic neuron proliferation and neuroblastoma predisposition. Development 2011, 138:4699-4708

19. Montavon G, Jauquier N, Coulon A, Peuchmaur M, Flahaut M, Bourloud KB, Yan P, Delattre O, Sommer L, Joseph JM, JanoueixLerosey I, Gross N, Muhlethaler-Mottet A: Wild-type ALK and activating ALK-R1275Q and ALK-F1174L mutations upregulate Myc and initiate tumor formation in murine neural crest progenitor cells. Oncotarget 2014, 5:4452-4466

20. Stoica GE, Kuo A, Aigner A, Sunitha I, Souttou B, Malerczyk C, Caughey DJ, Wen D, Karavanov A, Riegel AT, Wellstein A: Identification of anaplastic lymphoma kinase as a receptor for the growth factor pleiotrophin. J Biol Chem 2001, 276:16772-16779

21. Stoica GE, Kuo A, Powers C, Bowden ET, Sale EB, Riegel AT, Wellstein A: Midkine binds to anaplastic lymphoma kinase (ALK) and acts as a growth factor for different cell types. J Biol Chem 2002, 277:35990-35998

22. Nakagawara A, Milbrandt J, Muramatsu T, Deuel TF, Zhao H, Cnaan A, Brodeur GM: Differential expression of pleiotrophin and midkine in advanced neuroblastomas. Cancer Res 1995, 55: $1792-1797$

23. Fiegel HC, Kaifi JT, Wachowiak R, Quaas A, Aridome K, IchiharaTanaka K, Muramatsu T, Metzger R, Izbicki JR, Erttmann R, Kluth D, Till H: Midkine is highly expressed in neuroblastoma tissues. Pediatr Surg Int 2008, 24:1355-1359

24. Brodeur GM, Pritchard J, Berthold F, Carlsen NL, Castel V, Castelberry RP, De Bernardi B, Evans AE, Favrot M, Hedborg F: Revisions of the international criteria for neuroblastoma diagnosis, staging, and response to treatment. J Clin Oncol 1993, 11:1466-1477

25. Thiele CJ: Neuroblastoma. Edited by Masters J. Human cell culture. Lancaster, UK, Kluwer Academic Publishers, 1998

26. Ferrandis E, Da Silva J, Riou G, Benard I: Coactivation of the MDR1 and MYCN genes in human neuroblastoma cells during the metastatic process in the nude mouse. Cancer Res 1994, 54:2256-2261

27. Vassal G, Terrier-Lacombe MJ, Bissery MC, Venuat AM, Gyergyay F, Benard J, Morizet J, Boland I, Ardouin P, Bressac-de-Paillerets B, Gouyette A: Therapeutic activity of CPT-11, a DNA-topoisomerase I inhibitor, against peripheral primitive neuroectodermal tumour and neuroblastoma xenografts. Br J Cancer 1996, 74:537-545

28. Whiteford CC, Bilke S, Greer BT, Chen Q, Braunschweig TA, Cenacchi N, Wei JS, Smith MA, Houghton P, Morton C, Reynolds CP, Lock R, Gorlick R, Khanna C, Thiele CJ, Takikita M, Catchpoole D, Hewitt SM, Khan J: Credentialing preclinical pediatric xenograft models using gene expression and tissue microarray analysis. Cancer Res 2007, 67:32-40

29. Calvet L, Santos A, Valent A, Terrier-Lacombe MJ, Opolon P, Merlin JL, Aubert G, Morizet J, Schellens JH, Benard J, Vassal G: No topoisomerase I alteration in a neuroblastoma model with in vivo acquired resistance to irinotecan. Br J Cancer 2004, 91:1205-1212

30. Vacherot F, Delbe J, Heroult M, Barritault D, Fernig DG, Courty J: Glycosaminoglycans differentially bind HARP and modulate its biological activity. J Biol Chem 1999, 274:7741-7747

31. Mazot P, Cazes A, Boutterin MC, Figueiredo A, Raynal V, Combaret V, Hallberg B, Palmer RH, Delattre O, Janoueix-Lerosey I, Vigny M: The constitutive activity of the ALK mutated at positions F1174 or R1275 impairs receptor trafficking. Oncogene 2011, 30: 2017-2025

32. Lu KV, Jong KA, Kim GY, Singh J, Dia EQ, Yoshimoto K, Wang MY, Cloughesy TF, Nelson SF, Mischel PS: Differential induction of glioblastoma migration and growth by two forms of pleiotrophin. J Biol Chem 2005, 280:26953-26964

33. Polykratis A, Delbe J, Courty J, Papadimitriou E, Katsoris P: Identification of heparin affin regulatory peptide domains with potential role on angiogenesis. Int J Biochem Cell Biol 2004, 36: $1954-1966$

34. Yamamoto K, Ohta S, Ito E, Hayashi Y, Asami T, Mabuchi O, Higashigawa M, Tanimura M: Marginal decrease in mortality and 
marked increase in incidence as a result of neuroblastoma screening at 6 months of age: cohort study in seven prefectures in Japan. J Clin Oncol 2002, 20:1209-1214

35. Woods WG, Gao RN, Shuster JJ, Robison LL, Bernstein M, Weitzman S, Bunin G, Levy I, Brossard J, Dougherty G, Tuchman M, Lemieux B: Screening of infants and mortality due to neuroblastoma. N Engl J Med 2002, 346:1041-1046

36. Galkin AV, Melnick JS, Kim S, Hood TL, Li N, Li L, Xia G, Steensma R, Chopiuk G, Jiang J, Wan Y, Ding P, Liu Y, Sun F, Schultz PG, Gray NS, Warmuth M: Identification of NVP-TAE684, a potent, selective, and efficacious inhibitor of NPM-ALK. Proc Natl Acad Sci U S A 2007, 104:270-275

37. Iwahara T, Fujimoto J, Wen D, Cupples R, Bucay N, Arakawa T, Mori S, Ratzkin B, Yamamoto T: Molecular characterization of ALK, a receptor tyrosine kinase expressed specifically in the nervous system. Oncogene 1997, 14:439-449

38. Pulford K, Lamant L, Morris SW, Butler LH, Wood KM, Stroud D, Delsol G, Mason DY: Detection of anaplastic lymphoma kinase (ALK) and nucleolar protein nucleophosmin (NPM)-ALK proteins in normal and neoplastic cells with the monoclonal antibody ALK1. Blood 1997, 89:1394-1404

39. Wang YW, Tu PH, Lin KT, Lin SC, Ko JY, Jou YS: Identification of oncogenic point mutations and hyperphosphorylation of anaplastic lymphoma kinase in lung cancer. Neoplasia 2011, 13: $704-715$

40. Yang JJ, Zhang XC, Su J, Xu CR, Zhou Q, Tian HX, Xie Z, Chen HJ, Huang YS, Jiang BY, Wang Z, Wang BC, Yang XN, Zhong WZ, Nie Q, Liao RQ, Mok TS, Wu YL: Lung cancers with concomitant EGFR mutations and ALK rearrangements: diverse responses to EGFR-TKI and crizotinib in relation to diverse receptors phosphorylation. Clin Cancer Res 2014, 20:1383-1392

41. Schonherr C, Ruuth K, Yamazaki Y, Eriksson T, Christensen J, Palmer RH, Hallberg B: Activating ALK mutations found in neuroblastoma are inhibited by Crizotinib and NVP-TAE684. Biochem J 2011, 440:405-413

42. Bresler SC, Wood AC, Haglund EA, Courtright J, Belcastro LT, Plegaria JS, Cole K, Toporovskaya Y, Zhao H, Carpenter EL, Christensen JG, Maris JM, Lemmon MA, Mosse YP: Differential inhibitor sensitivity of anaplastic lymphoma kinase variants found in neuroblastoma. Sci Transl Med 2011, 3:108ra14

43. Kuo AH, Stoica GE, Riegel AT, Wellstein A: Recruitment of insulin receptor substrate-1 and activation of NF-kappaB essential for midkine growth signaling through anaplastic lymphoma kinase. Oncogene 2007, 26:859-869
44. Moog-Lutz C, Degoutin J, Gouzi JY, Frobert Y, Brunet-de Carvalho N, Bureau J, Creminon C, Vigny M: Activation and inhibition of anaplastic lymphoma kinase receptor tyrosine kinase by monoclonal antibodies and absence of agonist activity of pleiotrophin. J Biol Chem 2005, 280:26039-26048

45. Mathivet $\mathrm{T}$, Mazot $\mathrm{P}$, Vigny $\mathrm{M}$ : In contrast to agonist monoclonal antibodies, both C-terminal truncated form and full length form of Pleiotrophin failed to activate vertebrate ALK (anaplastic lymphoma kinase)? Cell Signal 2007, 19:2434-2443

46. Perez-Pinera P, Zhang W, Chang Y, Vega JA, Deuel TF: Anaplastic lymphoma kinase is activated through the pleiotrophin/receptor protein-tyrosine phosphatase beta/zeta signaling pathway: an alternative mechanism of receptor tyrosine kinase activation. J Biol Chem 2007, 282:28683-28690

47. Zhu S, Lee JS, Guo F, Shin J, Perez-Atayde AR, Kutok JL, Rodig SJ, Neuberg DS, Helman D, Feng H, Stewart RA, Wang W, George RE, Kanki JP, Look AT: Activated ALK collaborates with MYCN in neuroblastoma pathogenesis. Cancer Cell 2012, 21: 362-373

48. Berry T, Luther W, Bhatnagar N, Jamin Y, Poon E, Sanda T, Pei D, Sharma B, Vetharoy WR, Hallsworth A, Ahmad Z, Barker K, Moreau L, Webber H, Wang W, Liu Q, Perez-Atayde A, Rodig S, Cheung NK, Raynaud F, Hallberg B, Robinson SP, Gray NS, Pearson AD, Eccles SA, Chesler L, George RE: The ALK(F1174L) mutation potentiates the oncogenic activity of MYCN in neuroblastoma. Cancer Cell 2012, 22:117-130

49. Heukamp LC, Thor T, Schramm A, De Preter K, Kumps C, De Wilde B, Odersky A, Peifer M, Lindner S, Spruessel A, Pattyn F, Mestdagh P, Menten B, Kuhfittig-Kulle S, Kunkele A, Konig K, Meder L, Chatterjee S, Ullrich RT, Schulte S, Vandesompele J, Speleman F, Buttner R, Eggert A, Schulte JH: Targeted expression of mutated ALK induces neuroblastoma in transgenic mice. Sci Trans Med 2012, 4:141ra91

50. Sasaki T, Okuda K, Zheng W, Butrynski J, Capelletti M, Wang L, Gray NS, Wilner K, Christensen JG, Demetri G, Shapiro GI, Rodig SJ, Eck MJ, Janne PA: The neuroblastoma-associated F1174L ALK mutation causes resistance to an ALK kinase inhibitor in ALK-translocated cancers. Cancer Res 2010, 70: 10038-10043

51. Heuckmann JM, Holzel M, Sos ML, Heynck S, Balke-Want H, Koker M, Peifer M, Weiss J, Lovly CM, Grutter C, Rauh D, Pao W, Thomas RK: ALK mutations conferring differential resistance to structurally diverse ALK inhibitors. Clin Cancer Res 2011, 17: 7394-7401 